\title{
多様な津波発生を考慮した南海地震津波の再考
}

\section{Revisiting the Great Nankai Trough Earthquake Tsunami Considering the Uncertainty of Source}

\author{
鈴木進吾 ${ }^{1} \cdot$ 河田惠昭 ${ }^{2}$ \\ Shingo SUZUKI and Yoshiaki KAWATA
}

\begin{abstract}
The gap between predicted tsunami height and the realized that increased the amount of damage and delivered a lot of difficulties on the operations of the 2011 Great East Japan Earthquake Disaster. In this paper, the authors analyzed the stochastic property of resultant tsunami height considering the uncertainty in source parameters. Tsunami height at each site is estimated using probabilistic simulations and represented as a probability density function or inverse distribution function. Using these probabilistic description, we can evaluate not only probable maximum tsunami height but also most typical tsunami height at each site or the probability that tsunami will exceed the assumed tsunami height. And combining this with the level of tsunami preparedness, we can revisit the progress of countermeasures quantitatively.
\end{abstract}

\section{1. 序論}

平成 23 年東北地方太平洋沖地震によって発生した津波 は, 特に岩手, 宮城, 福島の 3 県各沿岸域において, 従 前の想定外力を大幅に超え, 想定を超える時空間の被害 と災害対応の発生をもたらした（例えば，中央防災会議 東北地方太平洋沖地震を教訓とした地震 ・津波刘策に関 する専門調査会，2011）。これは，次にどのような特性 を持つ津波が発生するかを一意に決められないという状 況下においてしかるべき対策を進めるためには, 考えう る範囲内であらゆる津波外力の来襲可能性を評価し, そ の結果を用いて政府・自治体や地域住民が社会の防災力 と比較し, 防災・減災対策の整備目標を検討できるょう にする必要性を示したといえる.

本研究では, 多様な津波波源を考えた場合の, 南海地 震の想定被災地域沿岸部における津波高ごとの来襲可能 性を評価した。波源特性を多様に変化させて考えた場合, 地域に来襲する津波高は, 波源に対するその地域の地理 的かつ地形的条件からどのような確率分布を持つかを調 べた，それと同時に，来襲する津波は地域によって特定 の確率分布を持つことを示し, それぞれの地域でどのよ うな津波高を想定するべきか, さらに，想定值を超える 可能性がどれだけあるかを定量的に示すことによって， 想定を超える事象の発生に備えた対策の検討に資するこ と目指した.

\section{2. 津波災害の想定上の課題}

これまでの津波による被害想定では, まず, 地震研究

1 正会員 博(情) 京都大学助教防災研究所

2 フエロー 工博関西大学教授大学院社会安全研究科
者による断層モデルの提示があり, それに基づいて数值 計算を行って被害を推定してきた。しかしながら，東日 本大震災のように地震マグニチュード（本稿では断らな い限り，モーメントマグニチュードを指している） 9.0 と いう想定以上の地震が発生すると, 事前に予測した津波 高さを遥かに凌駕する巨大津波が来襲するため, 八ザー ドマップに代表されるように, 用意してきた事前・事中 の対策効果は限定されたものとなる。 それどころか住民 に安全だと思わせたきらいもある.

このようなことの反省から, 津波防災における想定に 対する考え方を抜本的に見なおして, 今後, 想定が原因 となって津波被害が拡大することがないように, 工夫が 必要である. 本章ではその課題と対策を整理する.

\section{（1）断層モデルの固定化}

地震研究により力学的な観点から断層パラメターが提 示されてきた. 1つの断層モデルを, 地震マグニチュー ドはもとより, 断層パラメターのすべてが, 所与の条件 として数值で与えられることによって, 利用者により断 層モデルのすべてのパラメターは決定論的に捉えられ る.一旦パラメターが変化すれば, 確率的に想定を超え る津波が来襲することになる．利用者はこのことを念頭 に扔かなければならない。

断層モデルは地震マグニチュードを含め，8個のパラ メターで記述される。このパラメターセットは, プレー 卜境界の制限に基づいた物理的に起こり得る範囲におい て, 多様に存在すると考える. この範囲内において, 各 パラメターを系統的に変化させ, それぞれのモデルを用 いて地域に到達する津波の高さを求め, その統計を取る と, 地域に到達する津波の高さは, 1つに定まるもので はなく, パラメターの取り方, 即ち地震の発生の仕方と, 地域の地理的位置, および波源から地域までの海底地形 
表-1 本研究で想定した 7 つの゚ラメターの範囲, 変化の間隔, ケース数

\begin{tabular}{c|c|c|c}
\hline パラメター & 想定の範囲 & 感覚 & 感覚 \\
\hline 位 置 & 図-1 参照 & - & 10 \\
\hline 深 さ & $2 \sim 20 \mathrm{~km}$ & $2 \mathrm{~km}$ & 10 \\
\hline 縦横比 & $0.6 \sim 2.4($ 長さ $/$ 幅 $)$ & 0.2 & 10 \\
\hline すベり量 & $5 \sim 50 \mathrm{~m}$ & $5 \mathrm{~m}$ & 10 \\
\hline 傾斜角 & $10 \sim 55^{\circ}$ & $5^{\circ}$ & 10 \\
\hline 走 向 & $225 \sim 315^{\circ}$ & $10^{\circ}$ & 10 \\
\hline すベり角 & $70 \sim 115^{\circ}$ & $5^{\circ}$ & 10 \\
\hline
\end{tabular}

を反映させて，ばらつくものであることがわかる．

その後で，巨大津波を与える各パラメターの組み合わ せが，地震学的におかしくないかをチェックし，対策の 基準となる想定津波を設定する。このように，1つの想 定值のみならず，様々な想定值を出して，想定情報が決 定論的なものとして固定化されるのを防ぐ必要があると 考えられる.

\section{(2) 最大の津波}

過去に発生した最大規模の地震や津波は, 津波堆積物 の解析や海岸段丘の発生過程に関する検討によって, か なりの精度で推定できる.しかし，「起こり得る」巨大 地震や巨大津波は, このような取り扱いから求めること は不可能である。「自然は二度と同じ姿を見せてくれな い」と考えなければならない. 過去の数回の地震の実績 から, 各地域に到達する津波の高さの最大を決定するこ とは困難である。同時に最大であると決定することは, 前述のような東日本大震災での事例もあり，その外側の 住民にとっては非常に重大な決定となる.

最大值のみの情報だけではなく, 津波高の発生確率分 布，すなわち，その地域で発生する津波がどのくらいの 高さになりやすいのか, どの程度の高さの津波がどの程 度の確率で来襲するかを示す情報も, 限られた時間と資 源の中で対策を行う利用者側にとっては有用な情報と考 えられる，重要であるのは，津波による被害をできるだ け軽減するよう発生に向けた準備を継続することである. 初めから最大の津波に対して対策をとることができなく ても, 段階的に対応可能な津波高を上げていく必要があ る.その上では現状の防災力あるいは目標を定量的に評 価できる津波高の発生確率分布が重要となろう。ありと あらゆる可能性において津波の外力を考え，それをわか りやすい形，使いやすい形にすることが必要である.

\section{（3）自ら想定する社会}

従来の対策は, 外力の大きさが対策を決めるものであ った．災害を起こす側が対策内容を決めるというもので ある. 確たる「数值的」な根拠が無いと, 対策が行えな く, また, 外力の大きさが見直されるたびに, 対策を修

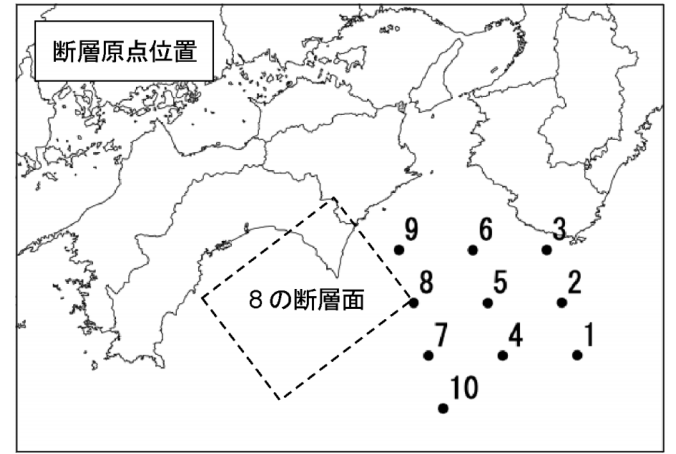

図-1 本研究で想定した 10 通りの断層原点位置

正しなければならないということになってしまうだろう.

減災対策によって被害を最小化することを目指すなら ば，私たちの社会の側が対策の基準や内容を決める，想 定值を決めるという本来の考え方が必要である. しかし ながらそれを行うだけの現状での不確定性を考慮した津 波高に関する十分な情報がない.

これまで述べた情報を作るためには, 津波研究者と地 震研究者, 災害対応や復興研究者, 行政, 地域住民の共 同研究によって可能となろう。しかし，長期間を要する 作業となることは必定であるから，まず，第一歩として 津波高の確率表示を次章以降で提案する.

\section{3. 不確定性を考慮した津波数値解析}

本研究では, 上述のような視点に立脚して, 南海地震 の想定被災域の沿岸各地における, 津波高の発生確率分 布を求める.

まず，津波波源の位置や形状が不確定であることを所 与条件とし, 波源を規定するパラメターを多様に変化さ せた，膨大な数の断層モデルを作成した，そして，その 膨大なケースの津波に関して数值解析を実施し, 沿岸各 地における津波高の発生確率分布を算出した.

\section{（1）断層パラメターの設定}

津波の波源は，地震マグニチュード（M)，断層原点の 位置, 断層上端の深さ, 断層面の縦横比（あるいは, 断 層面の長さまたは幅のいずれか), すべり量, 傾斜角, 走向, すべり角の8つのパラメターで規定される.

本研究では, まず, 南海地震の地震マグニチュードを M8.0，8.2，8.4の3 通りに固定して考える.そして，そ れぞれの地震マグニチュードについて，他の7つのパラ メターを表-1に示すように10通りずつ系統的に変化させ て想定した. 各断層パラメターの取りうる範囲は次のよ うに設定している.

a) 断層のほとんどが海域に位置することを条件とし て，図-1のように断層原点を設定した。

b) 断層深さは, 断層原点位置におけるプレート境界 


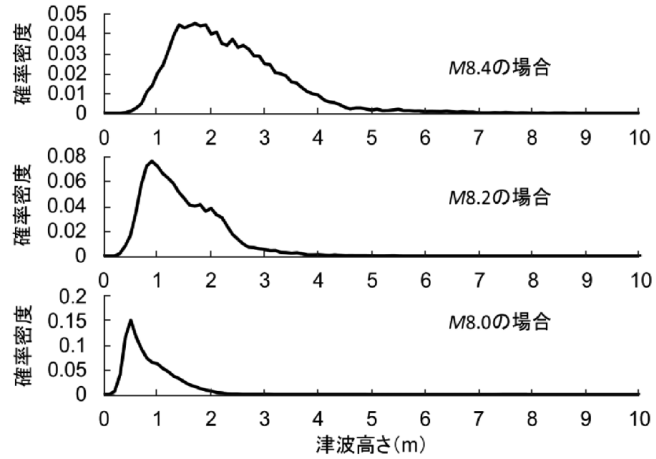

図-2 大阪における津波高さの確率密度分布

の深さを考慮して2〜20 km とした（例えば地震調 查研究推進本部地震調查委員会, 2001).

c）断層面の形状については地震マグニチュードが変 化しても同じ值を用いることができるので, 縦横 比を用いた．表-1に示した範囲はM8.4の場合に潮 岬を端点とした場合，紀伊水道をカバーする範囲 から，宮崎沖に至る範囲となる。

d）すべり量は，これまでの想定の程度から，最大で 東北地方太平洋沖地震津波の最大すべり量程度ま でとした.

e）傾斜角は様々な波長の津波を検討するために，10 度から 55 度の変化をつけた。

f）走向は陸側隆起の逆断層となるようにし，津波の指向 性が紀伊半島西岸から土佐湾西部を向くようにした。

g) すべり角については，90度を中心に，前後20〜25 度の範囲で変化させた。

(2) モンテカルロ・シミュレーション

これらの7つのパラメターが独立に各々 10 通り変化す るとした場合，それらで規定される波源モデルは，地震 マグニチュードごとに $10^{7}$ (=1千万) 通りとなる。これ らの波源モデルのすべてに対して, 津波数值解析を行う ことは計算資源と時間上の制約から不可能であったた め, この中から乱数を用いたランダム・サンプリングに より2万通りを抽出し, それらに対して津波数值解析を 実施するモンテカルロ・シミュレーションを行った。こ こでサンプリングするケース数を 2 万通りに設定したの は，10万通りまで計算した結果を用いて，集計後の頻度 分布の概形がほほ固定され始めるケース数を調べたとこ ろ，ほぼ2万通りであったからである。

各ケースの津波数值解析は, 非線形長波方程式を支配 方程式として，差分法によって行った．数值解析は，大 規模並列処理によって高速に計算させるため, 画像処理 装置による汎用計算（GPGPU）を利用した。空間解像度 は1350mとし，房総半島から九州東岸までの範囲を計算 領域とした、海岸は鉛直壁境界とし, 陸上への遡上は考
表-2 大阪における津波高に関する超過確率

\begin{tabular}{c|c|c|c}
\hline 津波高 & M8.4の場合 & M8.2の場合 & M8.0の場合 \\
\hline $1 \mathrm{~m}$ & $95 \%$ & $73 \%$ & $33 \%$ \\
\hline $2 \mathrm{~m}$ & $55 \%$ & $22 \%$ & $2 \%$ \\
\hline $3 \mathrm{~m}$ & $22 \%$ & $3 \%$ & $0.03 \%$ \\
\hline $4 \mathrm{~m}$ & $6 \%$ & $0.7 \%$ & $0 \%$ \\
\hline $5 \mathrm{~m}$ & $2 \%$ & $0.1 \%$ & $0 \%$ \\
\hline $6 \mathrm{~m}$ & $1 \%$ & $0 \%$ & $0 \%$ \\
\hline $7 \mathrm{~m}$ & $0.3 \%$ & $0 \%$ & $0 \%$ \\
\hline $8 \mathrm{~m}$ & $0.1 \%$ & $0 \%$ & $0 \%$ \\
\hline $9 \mathrm{~m}$ & $0 \%$ & $0 \%$ & $0 \%$ \\
\hline & & &
\end{tabular}

慮していない. 地震発生から6時間後までをシミュレー トした。その結果として沿岸の漁港・港湾414地点にお いて津波の高さを出力した. 1ケースあたりの計算実行 にかかる時間は 11 秒， 2 万回の計算を 2 日半で実施した.

最後に, 地点ごとに得られた 2 万個の津波高を集計し, 各地点の津波高に関する発生頻度分布を求めた。ここで は，どの波源モデルが生起しやすいかを相対的に決定す る資料が不足しているため, どの波源モデルに関しても その生起可能性は同じであるとして, 頻度分布を試行回 数で割ることにより, 確率密度 (相対確率) 分布とした. これは即ち, 津波波源の不確定性を考慮したときに, 各 地において, どのような津波高が発生しやすいか, どの 程度, 津波高がばらつきやすいかを示し, その地域の地 理的・地形的条件を考慮した津波危険度を示す.

\section{4. 津波外力の確率表示}

\section{（1）地域における津波外力の到達確率}

図-2は前章の方法によって計算された, 大阪における 津波高の確率密度分布である. 本研究の範囲内で断層パ ラメターを多様に変化させ様々なモデルを検討した場合, 大阪に来襲しうる津波の高さは, このモデルの多様性を 反映したばらつきを示すことが分かる．分布の凹凸は試 行回数を増やすことによってなめらかな曲線に近づく.

地震マグニチュードが大きくなると, 断層パラメター の不確定性による影響が大きくなる。これは, 地震マグ ニチュードが小さいときは, 津波が局所的となり不確定 性の影響が断層の周辺に限定的となるのに対して, 地震 マグニチュードが大きくなると, 断層の位置や形状その 他の幾何学的条件が多様になり, 大阪に来襲する津波の 大きさを大きく変化させるようになるからである.

また，それぞれのグラフにおいて，分布の特徴を考え ると, 津波高の小さい方へ傾くようになっている. 最尤 值を示す津波高と下限までの差より, 最尤值を示す津波 高と上限までの差の方が大きい. このことは, 最も起こ りやすい津波高は平均ではなく, それより大きい津波高 


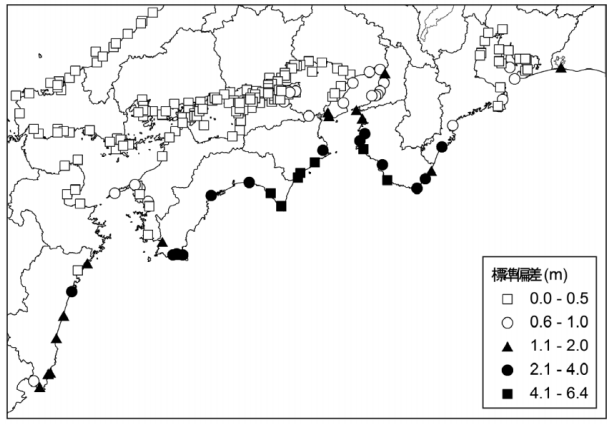

図-3 M8.4を想定した場合の各地に来襲する津波高さの標準 偏差

が発生する確率が高く，その值は分散している，という ことを表している．多様な津波波源を想定し計算するこ とによって，このような地域での津波高の発生特性を表 示することができるのである.

表-2 は大阪における津波高に関する超過確率である. ある津波高以上の確率を積分すると超過確率を計算する ことができる。これまでの中央防災会議の東海・東南 海・南海地震同時発生（M8.7）時の大阪における津波高 さである平均潮位時 T.P. $3.3 \mathrm{~m}$ は, M8.4の場合においても, 下限から $84.7 \%$ の位置にあり，これを超える確率は $15.3 \%$ あることが分かる．また，地震マグニチュードがM8.2 と 南海地震としては小さくても，この值を超える確率は $1.8 \%$ 存在するといったように評価することができる.

M8.4のとき，大阪では，最も相対的に確率が高くなる

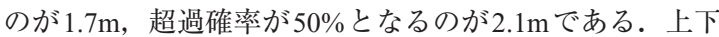
それぞれ $5 \%$ 程度を除いて考えると，90\%の確率で，津 波高は $1.0 \mathrm{~m}$ 以上 $4.1 \mathrm{~m}$ 未満の範囲に入ることが分かる. さらに平均潮位時にT.P. $4.4 \mathrm{~m} \sim 5.9 \mathrm{~m}$ で整備されている防 潮堤を超える確率は $1.1 \%$ ～3.8\% と評価され，大阪にと つて最悪の波源がこの割合程度，存在することが分かっ た。さらに，それぞれの高さの津波が来た場合に発生す る被害を想定して，この確率と掛け合わせることによっ て津波のリスクを定量化することができる.

図-3はM8.4を想定した場合の各地における津波高のば らつき具合を標準偏差で示したものである．外海部にお いて波源による津波高のばらつきが大きいことが分かる が，大阪湾の湾奥に位置する大阪においてもばらつきが 大きくなることが分かる．高知県西部から豊後水道にか けては小さい值となっているが，これは，波源の設定に 起因するものと考えられる。断層原点を紀伊水道沖に配 置すると，すべり量が大きくなるケースにおいては断層 面積が小さくなるため，高知県西部から豊後水道は波源 が遠くなり，この種の津波が到達しない，今後，このよ うにすべり量が大きくなる場合に限り，断層原点を西方 にも配置する工夫が必要である.

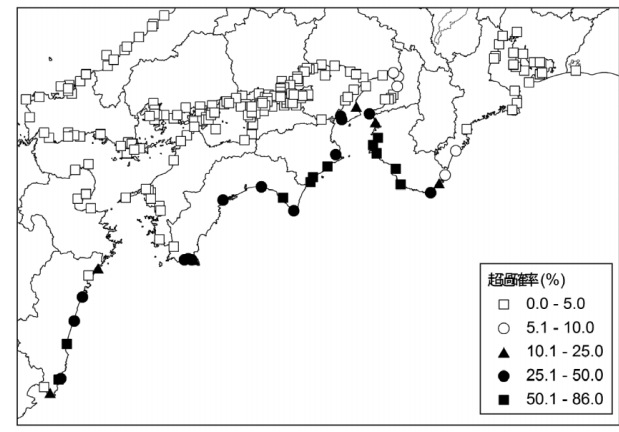

図-4 M8.4を想定した場合の各地で津波高が従来の想定を $2 \mathrm{~m}$ 以上超える確率

\section{（2）従来の想定を超える確率}

図-4はM8.4を想定した場合，各地においてこれまでの 想定を $2 \mathrm{~m}$ 以上超過する津波が来襲する確率を示したも のである。図-3で述べたのと同じの理由により，紀伊水 道沿岸で高い值を示しているものの，これに加え，宮崎 県においても高い值を示しており，波源の不確定性を含 んで，多様な津波を考えた場合，これまでの想定を大き く超える津波の発生可能性があることが分かった。これ らの地域においてはこれまでの想定を超えることが有り うることに注意して対策を検討していく必要がある.

ここでは，全体で一律に津波外力の既往の想定からの 超過幅を $2 \mathrm{~m}$ 以上と設定しているが，この值は各地域で の地形条件や現状の避難施設整備水準に鑑みて設定し, その超確率を計算することができる。このようにすれば, 地域での住民の避難方法や，これから地震発生までのま ちづくり，避難施設整備を考える上での指標となると考 えられる。

\section{（3）大すべり域・超大すべり域の確率的想定}

南海トラフの巨大地震モデル検討会（2012）は，東日 本大震災を教訓に，津波断層面の中で，特に大きくすべ る領域を「大すべり域」とし，大すべり域の中のトラフ 沿いの津波断層の領域については，津波地震を発生させ 「大すべり域」よりもさらに大きくすべる可能性がある として「超大すべり域」とするなど，特に大きい津波を 生起させる領域を設定している。

本研究では，この大すべり域を同様に確率的に検討し た。これまでに想定されていた，中央防災会議の東海・ 東南海・南海地震の同時発生モデル（M8.7）を背景断層 として，それに，M8.4程度の大すべり域を追加する。追 加後の地震マグニチュードはM8.7で変わらないが，大す べり域の存在のために，大きな津波が来襲する地域が発 生する.

図-5は和歌山・湯浅・御坊・田辺において，この解析 を行った結果得られた，確率密度分布である．従来の想 定津波に大すべり領域が発生した場合の，津波高の生起 


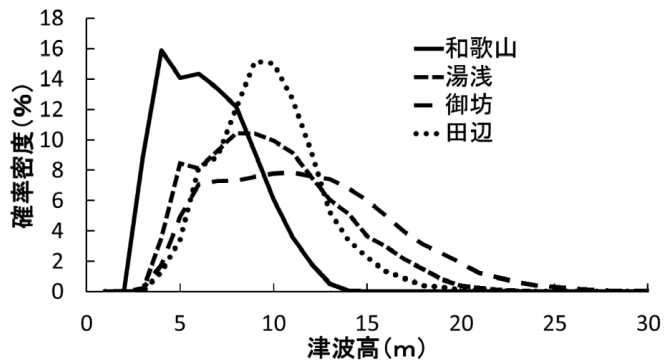

図-5 和歌山・湯浅・御坊・田辺の津波高さの確率密度分布

確率を表示している. 南海トラフの巨大地震モデル検討 会の示した最大值のみではなく, 最大でないケースの津 波高がどのように生起する確率があり, どの程度ばらつ くかを計算することができる。

\section{（4）大きな津波高をもたらす波源の特定}

本研究の手法により行った 2 万ケースの断層モデルの 中には, 断層モデルの特性によって, 地域に到達する津 波の高さが大きくなったケースがある。このケースを特 定することによって，各地域においてどのような断層モ デルが生起した場合に津波高が大きくなるかといった知 見を得ることができるのである。そして，そのような断 層モデルがどの程度の確率で生起する可能性があるかを 地震学的に検討することによって, どのようにその夕イ プの地震に準備すべきかを検討することができる.

図-6は大阪において，2万回の試行結果を，各種パラ メターとその時に大阪に来襲した津波高さとで1点ずつ プロットし，その間の関係を比較したグラフである．大 阪においては, 断層原点位置, 走向, 断層長さ, すべり 量の各パラメターで津波高に顕著な変化が見られた。こ の図から, 断層原点位置は, 徳島にもっとも近い位置に おいて, 走向は指向性が紀淡海峡の方向を向く走向にお いて，断層長さは $100 \mathrm{~km}$ 弱付近で, すべり量が大きくな るにつれて大阪での津波の高さが大きくなる傾向にある ことが分かった.

\section{5. 結論}

本研究では, 津波を発生させる断層の断層パラメター が不確定であることを考慮し，南海地震の想定被災域沿 岸への津波到達特性を再考した。 その結果得られた結論 を下記に列挙する.

a）波源を規定する断層パラメターの範囲を想定し， その範囲内にて多様な津波波源を生成し，数值計 算を行うことによって，地域での津波高を波源の 不確定性と地域の地理的地形的条件を反映した幅 を持った分布で表示することができた.

b）地震マグニチュードが大きくなるにつれて波源の 不確定性が影響し, 津波高のばらつきの幅が大き
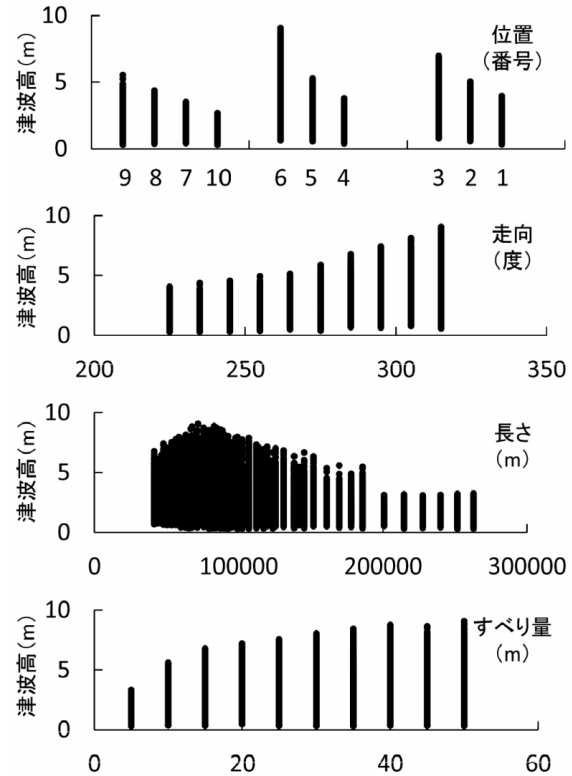

図-6 大阪の津波高さと各種パラメターの関係

くなることが分かった.

c）波源の不確定性を考慮した確率分布より，現在の 地域での津波想定高を超える確率，防潮堤整備水 準を超える確率，想定を $2 \mathrm{~m}$ 以上超える確率などが 計算された。これは対策の定量的検討に有用であ ると考えられる。

d）各地における波源の不確定性による津波高のばら つき具合は，特に外海部において大きく，また大 阪湾の湾奥部においても大きいことが分かった。

e）これまでの想定を $2 \mathrm{~m}$ 以上超過する確率は，紀伊水 道沿岸, 高知・宮崎県で高く, これまでの想定を 超える確率が大きいことに注意しておかなければ ならない.

f）本研究で提案した手法は，大すべり域の諸元が変 化したときの津波の発生確率も計算することがで き, 最大值のみではなく, 津波高の発生特性が検 討できる.

g) 多数の試行結果から, 各地において津波が高くなる 時の，断層パラメターの特性を知ることができる.

\section{参 考 文 献}

地震調查研究推進本部地震調查委員会 (2001) : 南海卜ラフの 地震の長期評価について，平成13年9月27日.

中央防災会議東北地方太平洋沖地震を教訓とした地震 ・津波 対策に関する専門調查会（2011）: 東北地方太平洋沖地震 を教訓とした地震・津波対策に関する専門調査会報告, 平成 23 年 9 月 28 日.

南海トラフの巨大地震モデル検討会 (2012) : 南海トラフの巨 大地震による震度分布・津波高について（第一次報告）, 平成 24 年3月31日. 